\title{
PI3 Gene
}

National Cancer Institute

\section{Source}

National Cancer Institute. PI3 Gene. NCI Thesaurus. Code C105389.

This gene plays a role in the inhibition of elastase activity. 